\title{
ANALISIS KADAR AKTIVITAS ANTIOKSIDAN, KADAR BESI, DAN pH PADA YOGURT SUSU KAMBING DENGAN PENAMBAHAN SARI KURMA (Phoenix dactylifera)
}

\author{
(Analysis of Antioxidant Activity, Iron and $\mathrm{pH}$ levels in Goat Milk Yogurt with \\ Addition of Date Extract (Phoenix dactylifera))
}

\author{
Endah Budi Permana Putri ${ }^{*}$, Rahayu Anggraini ${ }^{\mathrm{b}}$ \\ ${ }^{a} F a k u l t a s$ Kesehatan, Universitas Nahdlatul Ulama Surabaya, Indonesia \\ ${ }^{b}$ Fakultas Keperawatan dan Kebidanan, Universitas Nahdlatul Ulama Surabaya, Indonesia \\ * Penulis Korespondensi \\ Email: endah.budi92@unusa.ac.id
}

\begin{abstract}
Prevention of the COVID-19 virus can be done by increasing the body's immunity by consuming functional foods, one of which is yogurt. Goat milk has an unpleasant taste so that it is processed into yogurt and the addition of date palm extract is preferred. On the other hand, goat's milk and dates have high iron content. The materials used were fresh goat's milk, lactic acid bacteria, Ajwa dates, and date extract. The method used to analyze the levels of antioxidant activity is IC50 (Inhibition Concentration 50 Value), iron ( $\mathrm{Fe}$ ) levels using UV-Vis spectrophotometer, and $\mathrm{pH}$ value using a $\mathrm{PH}$-meter. The results showed that goat's milk yogurt with the addition of date palm extract had a very weak antioxidant content based on the IC50 antioxidant analysis method. There is a significant difference in iron levels in goat milk yogurt with the addition of ajwa date palm extract with the highest value $(5,7827 \mathrm{mg} / 100 \mathrm{~g})$ when compared to goat's milk yogurt with the addition of commercial date extract (5,2351 $\mathrm{mg} / 100 \mathrm{~g})$, goat's milk yogurt $(4,4348 \mathrm{mg} / 100 \mathrm{~g})$ and cow's milk yogurt $(3,6839 \mathrm{mg} / 100 \mathrm{~g})$. There are differences in the $\mathrm{pH}$ value of cow's milk yogurt and goat's milk yogurt, but the difference is not significantly different in yogurt with the addition of ajwa dates and commercial dates extract.
\end{abstract}

Keywords: Antioxidant Activity, Iron, ph, Goat Milk Yogurt, Date

\begin{abstract}
ABSTRAK
Pencegahan virus COVID-19 dapat dilakukan dengan meningkatkan imunitas tubuh dengan mengkonsumsi pangan fungsional salah satunya yaitu yogurt. Susu kambing memiliki rasa yang kurang disukai sehingga dengan diolah menjadi yogurt dan penambahan sari kurma dapat lebih disukai. Di sisi lain, susu kambing dan kurma memiliki kandungan besi yang tinggi. Bahan yang digunakan yaitu susu kambing segar, bakteri asam laktat, kurma ajwa, dan sari kurma. Metode yang digunakan untuk menganalisis kadar aktivitas antioksidan adalah $\mathrm{IC}_{50}$ (Inhibition Concentration 50 Value), kadar besi (Fe) yaitu spektrofotometer UV - Vis, dan nilai pH menggunakan PH-meter. Hasil penelitian menunjukkan bahwa yogurt susu kambing dengan penambahan sari kurma memiliki kandungan antioksidan yang sangat lemah berdasarkan metode analisis antioksidan $\mathrm{IC}_{50}$. Ada perbedaan signifikan kadar besi pada yogurt susu kambing dengan penambahan sari kurma ajwa dengan nilai paling tinggi $(5,7827 \mathrm{mg} / 100 \mathrm{~g})$ bila dibandingkan dengan yogurt susu kambing dengan penambahan sari kurma komersial $(5,2351$ $\mathrm{mg} / 100 \mathrm{~g})$, yogurt susu kambing $(4,4348 \mathrm{mg} / 100 \mathrm{~g})$ dan yogurt susu sapi $(3,6839 \mathrm{mg} / 100 \mathrm{~g})$. Terdapat perbedaan nilai $\mathrm{pH}$ pada yogurt susu sapi dan yogurt susu kambing namun perbedaan tidak berbeda nyata pada yogurt dengan penambahan sari kurma ajwa dan komersial.
\end{abstract}


Kata kunci: Aktivitas Antioksidan, Besi, pH, Yogurt Susu Kambing, Kurma

\section{PENDAHULUAN}

COVID-19 merupakan nama yang diberikan oleh WHO untuk pasien yang terinfeksi oleh virus novel corona 2019 yang pertama kali ditemukan di Wuhan, Cina pada akhir tahun 2019 (Handayani dkk, 2020). Kemudian pada awal tahun 2020, COVID-19 mulai menginfeksi warga Indonesia dan masih berlangsung hingga akir tahun 2020. Salah satu alternatif pencegahan yang dapat dilakukan untuk mengurangi laju penyebaran yaitu dengan meningkatkan daya tahan tubuh melalui asupan makanan sehat dan bergizi. Moghaddam (2020) dalam konferensinya mengatakan, konsumen ingin melindungi diri dan meningkatkan kekebalan tubuhnya dengan menerapkan pola makan yang lebih sehat, sehingga ketersediaan bahan makanan bioaktif dan makanan fungsional menjadi penting dan permintaan akan produk ini dapat meningkat.

Pangan fungsional yaitu produk yang didalamnya terkandung senyawa aktif biologis yang memberikan manfaat kesehatan, dapat dibuktikan secara klinis dan dapat digunakan untuk mencegah maupun mengobati melalui mekanisme biologis (Martirosyan dan Singh, 2015). Salah satu pangan fungsional yang sudah banyak dikenal yaitu yogurt. Yogurt biasa diproduksi melalui proses fermentasi susu dengan menggunakan bakteri Lactobacillus bulgaricus dan Streptococcus thermophillus. Hasil fermentasi ini menjadikan cita rasa susu menjadi asam (Savitry, 2016). Aktivitas dari kedua bakteri ini dapat menguraikan gula susu (laktosa) menjadi asam laktat. Adanya asam laktat inilah yang membuat yogurt terasa asam. Selain itu, proses fermentasi yang terjadi pada pembuatan yogurt menyebabkan kadar glukosa dalam yogurt berkurang sehingga aman dikonsumsi.

Pemilihan susu kambing menjadi bahan utama pembuatan yogurt karena susu kambing kaya akan komponen fungsional yang diperlukan oleh tubuh diantaranya, protein, vitamin $\mathrm{C}$ dan $\mathrm{E}$, flavonoid dengan sifat antioksidannya dan antiinflamasi, serta bahan pembentuk oksidan alami (sistein, seng, dan besi) (Sarah H. 2013). Berdasarkan hasil penelitian Alfiarahma dan Bambang (2015), didapatkan hasil bahwa adanya kandungan besi didalam susu kambing dapat meningkatkan kadar homoglobin pada hewan ujinya. Kandungan antioksidan alami dalam susu kambing dapat meningkatkan enzim SOD dalam mencegah terjadinya lisis pada sel erirosit dan kandungan besi (Fe). Sementara itu, berdasarkan hasil penelitian Harmoko (2017), kurma dapat dijadikan solusi untuk meningkatkan kadar hemoglobin dalam darah dengan konsumsi kurma sebanyak $100 \mathrm{gr}$ dalam sehari dan dikonsumsi pada pagi hari menunjukkan peningkatan sebesar $1,54 \pm 1,12 \mathrm{~g} / \mathrm{dl}$. Selain itu dalam konteks lain dengan pemberian sari kurma murni sebanyak $10 \mathrm{ml} 3$ kali dalam sehari juga dapat menunjukkan peningkatan sebesar 1gr/dl (Retno Widodo, dkk. 2019).

Berdasarkan latar belakang tersebut maka peneliti tertarik melakukan penelitian mengenai analisis kadar aktivitas antioksidan, kadar besi, dan $\mathrm{pH}$ pada yogurt susu kambing dengan penambahan sari kurma (Phoenix dactylifera). Diharapkan dengan adanya penelitian ini dapat dijadikan alternatif pangan fungsional yang dapat dikonsumsi. Selain itu juga diharapkan masyarakat tergugah untuk mengkonsumsi yogurt susu kambing dengan penambahan sari kurma setelah mengetahui kandungan gizi yang dimiliki oleh produk tersebut.

\section{BAHAN DAN METODE}

\section{Bahan}

Yogurt merupakan produk susu hasil fermentasi bakteri Streptococcus thermopilus dan Lactobacilus bulgaricus. 
Susu yang digunakan dalam penelitian ini berupa susu kambing segar dari CV. Bumiku Hijau. Sari kurma ajwa yang digunakan yaitu Sari Kurma Al Jazira dan kurma Ajwa Safiya Super.

\section{Pembuatan Sari Kurma Ajwa}

Sebanyak 7 buah kurma Ajwa dipisahkan antara daging dengan bijinya, kemudian daging kurma dilumatkan sehingga diperoleh sari kurma Ajwa.

\section{Pembuatan Yogurt Susu Kambing dengan Penambahan Sari Kurma}

Sebanyak 1 liter susu kambing segar dipasteurisasi pada suhu $85^{\circ} \mathrm{C}$ selama 15 menit kemudian didinginkan hingga suhu $40-45^{\circ} \mathrm{C}$ lalu ditambahkan bakteri Lactobacillus bulgaricus dan Streptococus thermopillus. Selanjutnya diinkubasi pada suhu $37^{\circ} \mathrm{C}$ selama 24 jam. Kemudian diambil $200 \mathrm{ml}$ yogurt susu kambing dan ditambahkan ekstrak sari kurma Ajwa (pada sampel sari kurma ajwa), dan diambil $200 \mathrm{ml}$ yogurt susu kambing dan ditambahkan 1 sdm sari kurma komersil (pada sampel sari kurma komersil).

\section{Analisis Aktivitas Antioksidan}

Metode yang digunakan untuk menganalisis kadar aktivitas antioksidan adalah $\mathrm{IC}_{50}$ (Inhibition Concentration 50 Value). $\mathrm{IC}_{50}$ merupakan konsentrasi yang dapat menghambat aktivitas dari radikal bebas DPPH sebanyak 50\%. Semakin kecil nilai $I_{50}$ maka semakin besar pula aktivitas antioksidan pada bahan pangan (Molyneux, 2004). Pelarut yang digunakan yaitu methanol.

\section{Analisis Kadar Besi (Fe)}

Metode yang digunakan untuk menganalisis kadar besi (Fe) yaitu spektrofotometer UV - Vis.

\section{Analisis pH}

Analisis $\mathrm{pH}$ pada sampel diketahui dengan menggunakan alat $\mathrm{pH}$-meter.

\section{Analisis Statistik}

Data yang diperoleh pada penelitian ini yaitu kadar aktivitas antioksidan akan dianalisis deskriptif, sedangkan kadar besi (Fe) dan $\mathrm{pH}$ dilakukan uji parametrik menggunakan uji one-way anova dan dilanjutkan dengan menggunakan uji post hoct untuk mengetahui adanya perbedaan antar variasi sampel. Data dianalisis menggunakan SPSS versi 16 dengan tingkat kepercayaan $5 \%$.

\section{HASIL DAN PEMBAHASAN Kadar Aktivitas Antioksidan}

Menurut Jeki, Zilfanita dan Dedi (2019), aktivitas antioksidan yaitu molekul yang dapat menghambat oksidasi dari molekul lain yang disebabkan oleh adanya radikal bebas, dengan mengetahui aktivitas antioksidan maka dapat pula diketahui mekanisme antioksidan dalam tubuh. Metode analisis aktivitas antioksidan yang digunakan pada penelitian ini untuk mengetahui kekuatan antioksidan yaitu $\mathrm{IC}_{50}$ (Inhibition Concentration 50 Value). $\quad \mathrm{IC}_{50}$ merupakan konsentrasi yang dapat menghambat aktivitas dari radikal bebas DPPH sebanyak $50 \%$. Semakin kecil nilai $\mathrm{IC}_{50}$ maka semakin besar pula aktivitas antioksidan pada bahan pangan (Molyneux, 2004).

Pada penelitian ini diketahui bahwa yogurt susu sapi, yogurt susu kambing maupun yogurt susu kambing dengan penambahan sari kurma memiliki kandungan antioksidan yang sangat lemah berdasarkan metode analisis antioksidan $\mathrm{IC}_{50}$. Hasil analisis kadar aktivitas antioksidan dapat dilihat pada Tabel 1.

Berdasarkan Tabel 1 diketahui bahwa kadar aktivitas antioksidan pada yogurt susu kambing dengan penambahan sari kurma ajwa memiliki nilai yang lebih kecil (5738,7143 ppm) bila dibandingkan dengan yogurt susu kambing dengan penambahan sari kurma komersial (6315,7143 ppm). Nilai tersebut cukup jauh bila dibandingkan dengan kadar aktivitas antioksidan pada yogurt susu kambing maupun susu sapi. 
Tabel 1. Hasil Analisis Kadar Aktivitas Antioksidan

\begin{tabular}{|c|c|c|}
\hline Variasi & $\mathrm{N}$ & Antioksidan IC50 (ppm) \\
\hline Yogurt Susu Sapi & 1 & 12250,7500 \\
\hline Yogurt Susu Kambing & 1 & 11377,7500 \\
\hline Yogurt Susu Kambing dengan Penambahan Sari Kurma Komersial & 1 & 6315,7143 \\
\hline Yogurt Susu Kambing dengan Penambahan Sari Kurma Ajwa & 1 & 5738,7143 \\
\hline
\end{tabular}

Tabel 2. Hasil Analisis Kadar Besi (mg/100g)

\begin{tabular}{lccc}
\hline & Variasi & Mean $\pm S D$ & $p$ value \\
\hline Yogurt Susu Sapi & 3 & $3,6839^{\mathrm{a}} \pm 0,02$ & \\
Yogurt Susu Kambing & 3 & $4,4348^{\mathrm{b}} \pm 0,05$ & 0,000 \\
Yogurt Susu Kambing dengan Penambahan Sari Kurma Komersial & 3 & $5,2351^{\mathrm{c}} \pm 0,04$ & \\
Yogurt Susu Kambing dengan Penambahan Sari Kurma Ajwa & 3 & $5,7827^{\mathrm{d}} \pm 0,03$ & \\
\hline
\end{tabular}

Keterangan: Notasi huruf yang berbeda menunjukkan hasil berbeda nyata

Tabel 3. Hasil Analisis nilai pH

\begin{tabular}{llll}
\hline Variasi & $N$ & Mean $\pm S D$ & $p$ value \\
\hline Yogurt Susu Sapi & 3 & $5,87^{\mathrm{a}} \pm 0,03$ & \\
Yogurt Susu Kambing & 3 & $5,62^{\mathrm{b}} \pm 0,03$ & \multirow{2}{*}{0,001} \\
Yogurt Susu Kambing dengan Penambahan Sari Kurma Komersial & 3 & $5,59^{\mathrm{b}} \pm 0,01$ & \\
Yogurt Susu Kambing dengan Penambahan Sari Kurma Ajwa & 3 & $5,64^{\mathrm{b}} \pm 0,11$ & \\
\hline
\end{tabular}

Keterangan: Notasi huruf yang berbeda menunjukkan hasil berbeda nyata

Sementara itu, aktivitas antioksidan pada yogurt susu kambing (11377,7500 ppm) lebih baik bila dibandingkan dengan yogurt susu sapi (12250,7500 ppm), hal tersebut tergambarkan dari nilai $\mathrm{IC}_{50}$, semakin kecil nilai $\mathrm{IC}_{50}$ maka semakin besar pula aktivitas antioksidan pada bahan pangan. Kandungan pada susu kambing yaitu kasein susu sebagai aktivitas antioksidan yang pengikat logam (metal 40 chelator) dan pengikat radikal bebas (Farvin et al., 2010; Alenisan et al., 2017). Sedangkan pada air rendaman kurma 24 jam mengandung flavonoid sebanyak 8, $08 \mathrm{mg} / \mathrm{L}$ (Putri, dkk, 2020). Flavonoid sendiri merupakan senyawa bioaktif yang berfungsi sebagai antioksidan.

\section{Kadar Besi (Fe)}

Hasil uji one way anova menunjukkan bahwa terdapat perbedaan kadar besi (Fe) yang signifikan $(p=0,000)$ pada yogurt susu sapi, yogurt susu kambing sebagai kontrol dengan yogurt susu kambing dan penambahan sari kurma baik sari kurma komersial maupun sari kurma ajwa. Sedangkan berdasarkan hasil uji Tukey, rata-rata kadar besi ( $\mathrm{Fe}$ ) pada tiap variasi sampel menunjukkan hasil yang berbeda nyata. Hasil analisis kadar besi ( $\mathrm{Fe}$ ) dapat dilihat pada Tabel 2.

Berdasarkan Tabel 2 diketahui bahwa rata-rata kadar besi (Fe) pada yogurt susu kambing dengan penambahan sari kurma ajwa memiliki nilai yang lebih tinggi $(5,7827$ $\mathrm{mg} / 100 \mathrm{~g}$ ) bila dibandingkan dengan yogurt susu kambing dengan penambahan sari kurma komersial $(5,2351 \mathrm{mg} / 100 \mathrm{~g})$. Sementara itu, yogurt susu kambing dengan penambahan sari kurma baik komersial maupun sari kurma ajwa memiliki kadar besi yang lebih tinggi bila dibandingkan dengan yogurt kontrol, baik pada yogurt susu kambing maupun yogurt susu sapi. Namun, yogurt susu kambing $(4,4348$ $\mathrm{mg} / 100 \mathrm{~g}$ ) memiliki kadar Fe yang lebih tinggi bila dibandingkan dengan yogurt susu sapi $(3,6839 \mathrm{mg} / 100 \mathrm{~g})$.

Menurut J Diaz-Castro et al. (2015), susu kambing memiliki manfaat yaitu meminimalkan interaksi kalsium dan besi (Ca-Fe) dan meningkatkan status $\mathrm{Fe}$ beserta penyerapannya, dapat meningkatkan biovailabilitas mineral $\mathrm{Cu}$ yang penting untuk erythropoiesis. Sementara itu, dalam kondisi kelebihan Fe, susu kambing mampu mempetahankan dan meningkatkan antioksidan dalam tubuh 
serta dapat membatasi peroksidasi lipid. Sehingga secara langsung, kandungan fe pada susu kambing akan dapat berubah fungsi menjadi pendungkung dalam mineralisasi tulang (khususnya paha dan dada) dalam proses hematopoietik. Dalam kejadian ini, fe mempengaruhi sintesis dan pematanagn kolagen tipe.1 dalam pergantian tulang. Fe sendiri merupakan kofaktor penting untuk prolyl dan lisis hidroksilase dalam fungsinya sebagai peningkatan osteoblas pada proses pembentukan tulang, serta dapat mengurangi efek samping kejadian anemia. Salah satu efek samping kejadian anemia yaitu dapat menyebabkan oksidatif stress dan biovailabilias mineral, dengan mengkonsumsi susu kambing dapat meningkatkan metabolisme fe, sehingga efek samping yang ditinggalkan saat terjadinya anemia sedikit ringan.

$\mathrm{Di}$ sisi lain, dengan adanya penambahan sari kurma maka kandungan Fe pada yogurt susu kambing dan sari kurma lebih tinggi dibandingkan pada yogurt susu kambing (kontrol). Hal ini disebabkan karena kurma memiliki kandungan zat besi sebanyak 1,2 mg sehingga apabila dikonsumsi maka akan meningkatkan kadar hemoglobin dalam darah (Febriansyah, 2013)

\section{Nilai $\mathbf{p H}$}

Hasil uji one way anova menunjukkan bahwa terdapat perbedaan nilai $\mathrm{pH}$ yang signifikan $(p=0,000)$ pada yogurt susu sapi, yogurt susu kambing sebagai kontrol dengan yogurt susu kambing dan penambahan sari kurma baik sari kurma komersial maupun sari kurma ajwa. Sementara itu dari hasil uji Tukey, rata-rata nilai $\mathrm{pH}$ pada yogurt susu sapi berbeda nyata dengan nilai $\mathrm{pH}$ pada yogurt susu kambing, maupun yogurt susu kambing dengan penambahan sari kurma komersial dan sari kurma ajwa. Hasil analisis nilai $\mathrm{pH}$ dapat dilihat pada Tabel 3.

Berdasarkan Tabel 3 diketahui bahwa rata-rata nilai $\mathrm{pH}$ pada yogurt susu kambing dengan penambahan sari kurma komersial memiliki nilai $\mathrm{pH}$ paling rendah yaitu sebesar 5,59. Nilai $\mathrm{pH}$ ini lebih rendah bila dibandingkan dengan kontrol yaitu pada yogurt susu sapi sebesar 5,87 dan pada yogurt susu kambing sebesar 5,62. Adanya penurunan $\mathrm{pH}$ pada yogurt yang diberi penambahan sari kurma komersial kemungkinan disebabkan karena pada sari kurma komersial tidak murni berasal dari kurma saja melainkan ada penambahan bahan lain yaitu glukosa sebesar $4,54 \%$ dan fruktosa sebesar 0,05\%. Sedangkan nilai $\mathrm{pH}$ pada yogurt susu kambing dengan penambahan ekstrak sari kurma ajwa mengalami kenaikan $\mathrm{pH}$ menjadi 5,64. Nilai $\mathrm{pH}$ ini sedikit mengalami peningkatan namun tidak berbeda nyata secara signifikan. Sehingga dengan adanya penambahan sari kurma baik komersial maupun sari kurma ajwa tidak berbeda nyata terhadap nilai $\mathrm{pH}$ yang dihasilkan. Namun, terdapat perbedaan yang nyata antara nilai $\mathrm{pH}$ yogurt yang berasal dari susu kambing dengan yogurt yang berasal dari susu sapi.

Kurma memiliki kandungan gula sederhana yaitu glukosa sebanyak $51,80 \%$ dan fruktosa sebanyak 47,50\% (Azhari et al., 2019). Gula tersebut yang berperan terhadap bakteri asam laktat untuk memberikan suasana asam dengan memberikan nutrisi pada bakteri sebagai bahan pangan untuk menjadi asam laktat dan menurunkan $\mathrm{pH}$. Hal ini sejalan dengan hasil penelitian Pranayanti dan Sutrisno (2015) yang menyatakan bahwa ketersediaan jumlah nutrisi akan membuat jumlah sel bakteri meningkat dan berdampak pada perombakan gula secara maksimal, sehingga total asam meningkat dan $\mathrm{pH}$ menurun.

KESIMPULAN
Yogurt susu kambing dengan
penambahan sari kurma memiliki
kandungan antioksidan yang sangat lemah
berdasarkan metode analisis antioksidan


$I_{50}$. Ada perbedaan signifikan kadar besi pada yogurt susu kambing dengan penambahan sari kurma ajwa dengan nilai paling tinggi $(5,7827 \mathrm{mg} / 100 \mathrm{~g})$ bila dibandingkan dengan yogurt susu kambing dengan penambahan sari kurma komersial $(5,2351 \mathrm{mg} / 100 \mathrm{~g})$, yogurt susu kambing $(4,4348 \mathrm{mg} / 100 \mathrm{~g})$ dan yogurt susu sapi $(3,6839 \mathrm{mg} / 100 \mathrm{~g})$. Terdapat perbedaan nilai $\mathrm{pH}$ yang signifikan $(\mathrm{p}=0,000)$ pada yogurt susu sapi dengan yogurt susu kambing dengan penambahan sari kurma namun perbedaan tersebut tidak beda nyata antara yogurt dengan penambahan sari kurma ajwa dengan yogurt dengan penambahan sari kurma komersial.

\section{UCAPAN TERIMA KASIH}

Ucapan terima kasih Kami sampaikan kepada kepala Lembaga Penelitian dan Pengabdian Masyarakat (LPPM) Universitas Nahdlatul Ulama Surabaya yang telah mendanai penelitian.

\section{DAFTAR PUSTAKA}

Alenisan, Modi A., Hanan H. Alqattan, Lojayn S. Tolbah, dan Amal B. Shori. 2017. Antioxidant Properties of Dairy Products Fortified with Natural Additives: A Review. Journal of the Association of Arab Universities for Basic and Applied Sciences. http://dx.doi.org/10.1016/j.jaubas.2017.0 5.001

Alfiarahma, Al \& Bambang Witjahyo, RB. 2015. Pengaruh Pemberian Susu Kambing Terhadap Gambaran Mikroskopis Paru dan Kadar Hemoglobin $(\mathrm{Hb})$ Tikus Wistar yang Terpapar Asap Kendaraan Bermotor. Fakultas Kedokteran. Universitas Diponegoro

Arasb Dabbagh Moghaddam. 2020. Covid19, Food Safety \& Nutrition (Prevention \& Control). Diakses pada 14 Oktober 2020.

https://www.researchgate.net/publication
/341607044 Covid-

19 Food Safety Nutrition Prevention Control

Azhari Siddeeg, Xin-An Zeng, Al-Farga Ammar, Zhong Han. Sugar Profile, Volatile Compounds, Composition and Antioxidant Activity of Sukkari Date Palm Fruit. Food Sci Technol. 2019 Feb; 56(2): 752-762

Danik M, Martirosyan \& Jaishree Singh. 2015. A New Definision of Functional Food by FFC: What Makes a New Definition Unique?. USA: Dalas University.

Diah Handayani, Dwi Rendra Hadi, Fathiyah Isbaniah, Erlina Burhan, Heidy Agustin. 2020. Penyakit Virus Corona 2019. Jurnal Respirologi Indonesia: Volume 40 No 2 April 2020 Hal 119-129

Endah Budi Permana Putri, Fildzah Karunia Putri, dan Siti Sulaiha. Perbandingan Kadar Flavonoid dan Vitamin C Pada Infused Water Goji Berry (Lycium barbarum) dan Air Nabeez Kurma (Phoenix dactylifera L.). Medical Technology and Public Health Journal. Volume 4 Issue 1: Hal 32-37

Farvin, K.H.S., Baron, C.P., Nielsen, N.S., Jacobsen, C. 2010. Antioxidant activity of yoghurt peptides: Part 1- in vitro assays and evaluation in $\mathrm{x}-3$ enriched milk. Food Chemistry. 123: 1081-1089.

Febriansyah H, Indriawati R. (2013). Pengaruh Pemberian Kurma (Phoenix dactilifera) dan Madu (Apex dorsalis) terhadap Kadar Hemoglobin pada Kelompok Usia 16 Sampai 18 Tahun. Fakultas Kedokteran dan IImu Kesehatan. Universitas Muhammadiyah Yogyakarta.

Harmoko. 2017. Efektifitas Pemberian Kurma Terhadap Kadar Hemoglobin pada Remaja Putri Anemia Di MA Tahfizh Nurul Iman Karanganyar. 
Program Studi Gizi. Stikes PKU Muhammadiyah. Surakarta

J Diaz-Castro, et al. 2015. Influence of Goat Milk on Iron Deficiency Anemia Recovery. Departement of Physiology. Faculty of Pharmacy. Universitas of Granada. Spain

Jeki M W, Zulfanita \& Dedi R. 2019. The Antioxidant Activity of Yogurt Drink by Mangosteen Rind Extract (Garcinia mangostana L.). Journal of Applied Food Technology 6(1) 15-18, doi:10.17728/jaft.4267 [On line]. Dari: http://ejournal2.undip.ac.id/index.php/jaft Molyneux. 2004. The Use of The Stable Free Radical Diphenylpicrylhydrazyl (DPPH) for Estimating Antioxidant Activity. Songklanakarin Journal Science Technology Volume 26 (2): 211-219

N I Savitry. 2016. Total Bakteri Asam Laktat, Total Asam, Nilai pH, Viskositas, Aktivitas Antioksidan dan Sifat Organoleptik Yogurt dengan
Penambahan Jus Buah Tomat. Program Studi Teknologi Pangan. Universitas Diponegoro. Semarang

Pranayanti, I. A. P., A. Sutrisno. 2015. Pembuatan minuman probiotik air kelapa muda (Cocos nucifera L.) dengan starter Lactobacillus casei strain Shirota. Jurnal Pangan dan Agroindustri. 3(2): 763-772.

Retno Widowati, Rini Kundaryanti, Puput Puji Lestari. 2019. Pengaruh Pemberian Sari Kurma Terhadap Peningkatan Kadar Hemoglobin Ibu Hamil. Jurnal Al Azhar Indonesia Seri Sains dan Teknologi. Volume 5 No 2 (2019). https://jurnal.uai.ac.id/index.php/SST/arti cle/view/351

Sarah H. 2013. Goat Milk's Immune Enchancing Properties. Happy Days Dairies Series. 